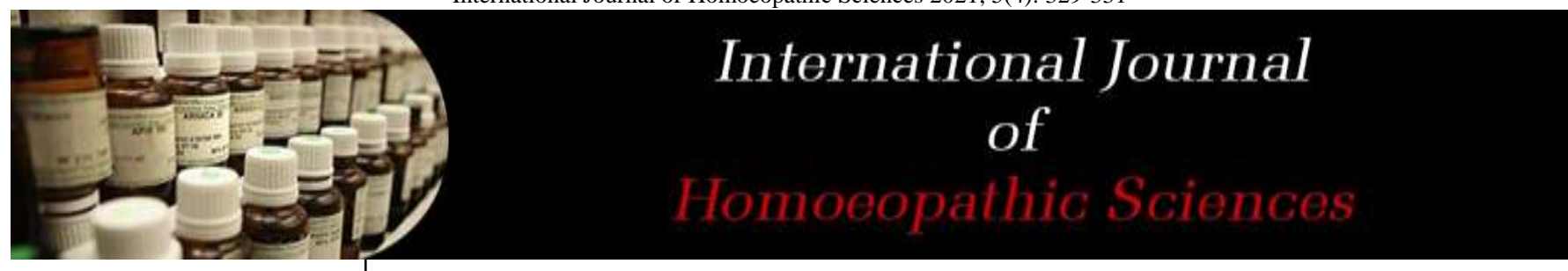

E-ISSN: $2616-4493$ P-ISSN: 2616-4485 www.homoeopathicjournal.com IJHS 2021; 5(4): 329-331

Received: 23-08-2021

Accepted: 25-09-2021

Dr. Lalit Tyagi

Ex-Post Graduate,

Trainee of National Institut of Homoeopathy, Kolkata, West Bengal, India
Corresponding Author:

Dr. Lalit Tyagi

Ex-Post Graduate

Trainee of National Institute

of Homoeopathy, Kolkata,

West Bengal, India

\section{Molluscum contagiosum treated with individualized homoeopathic medicine: A case report}

\author{
Dr. Lalit Tyagi \\ DOI: https://doi.org/10.33545/26164485.2021.v5.i4e.493
}

\begin{abstract}
Molluscum contagiosum is infectious, benign skin condition. Typically present with umbilicated papule. A 15-year-old male patient presented popular eruption on neck with itching. After clinical examination and characteristic umbilicated papule, it was diagnosed as case of molluscum contagiosum. On the basis of presentation and characteristic symptoms, the patient was treated with individualized homoeopathic medicine. After a span of 4 months the papules were found to be disappeared. Rationale of this particular case is to show the better outcome of molluscum contagiosum with individualized homoeopathic medicines.
\end{abstract}

Keywords: Individualized homoeopathic medicine, molluscum contagiosum, case report

\section{Introduction}

Molluscum contagiosum, also called water warts, is a benign condition of the skin [1, 2]. Molluscum contagiosum is a common infection of the skin is caused by molluscum contagiosum virus (MCV), which is a double-stranded DNA poxvirus of genus Molluscipoxvirus ${ }^{[3]}$. The person of $0-14$ years of age group are affected most with incidence as high as $12-14$ per 1000 children ${ }^{[4]}$, while considering the prevalence of molluscum contagiosum in general it ranges from 5.1-11.5\% in children ${ }^{[5]}$. Main mode of transmission of molluscum contagiosum lesions are direct skin-to-skin (including sexual) or indirect (towels, underclothes, toys, razor, tattoo supplies) contact ${ }^{[6]}$. In addition to this, Molluscum contagiosum may also spread by autoinoculation to normal skin after Mollusca scraping by the patients ${ }^{[7]}$. Other mode of spread are from sharing swimming pools and other wet environments is possible but not fully backed by evidence ${ }^{[8]}$. In order to diagnose the molluscum contagiosum, a clinical examination is needed, with characteristic umblicated papule it is not difficult to diagnosed ${ }^{[9]}$. Syringoma, Closed Comedones (whiteheads), and Warts (including anogenital ones) are the common differential diagnosis of molluscum contagiosum in children ${ }^{[10]}$. In the cases where diagnosis is difficult, dermoscopy, reflectance confocal microscopy, and histopathology, are useful tools ${ }^{[1]}$. In conventional medicine, Molluscum papule can be removed mechanically (using small skin curette, which can be incised with the needle or with a comedones extractor) or chemically (e.g. cantharidin, potassium hydroxide, podophyllotoxins etc.) ${ }^{[10,11]}$.

Most molluscum contagiosum lesions in non-compromised persons resolve spontaneously within an average duration of six to 12 months. However, the course of molluscum contagiosum may take as long as four years ${ }^{[1,12]}$.

\section{Case Presentation}

Male patient, SM, 15 years of age, came to our OPD, in NIH, Salt Lake on 16.01.2019. SM presented with papular eruption over the neck for 1 month, which was itchy and painless. For that, the patient had not taken any treatment. (Fig. 1 and fig. 2)

\section{Past history}

Dog bite one year ago for which he had vaccinated, chickenpox in childhood.

\section{Physical generals}

The patient was tall, thin and of dark complexion. Thermal reaction of the patient was hot. His appetite was good but cannot tolerate hunger. He has a desire for eggs, sour, onions, cold food and drinks, and aversion to sweets. His thirst was decreased and he drinks 1-2 liters of 
water per day. The sleep of the patient was sound and dreams of falling from height. The stool was satisfactory and urine was clear without any complaints. The tongue of the patient was moist and slightly coated.

\section{Mental generals}

Tensed and feels low about his look due to eruptions.

\section{Physical examination}

On examination, papular umbilicated eruption was noted, which were on the left side of the neck, up to face and small papule can be seen on the right side of the neck.

\section{Diagnosis}

Molluscum contagiosum, the diagnosis was made on physical examination and peculiar history.

\section{Characteristics}

Sad and concerned about cosmetic appearance

Thermal reaction- hot

Desire- egg, sour, onions, cold food and drink

Dreams- falling from height

Appetite- cannot tolerate hunger

Aversion- sweets

Tongue- moist and slightly coated.

\section{Repertorisation}

After appropriate evaluation of symptoms, repertorisation was done by Hompath firefly repertory software with using kent's repertory ${ }^{[5]}$ (figure-1).

\begin{tabular}{|c|c|c|c|c|c|}
\hline Remedy Name & Phos & Sulph & Cale & Thuj & Zine \\
\hline Totality / Symptom Covered & $11 / 6$ & $11 / 5$ & $9 / 4$ & $9 / 4$ & $8 / 5$ \\
\hline $\begin{array}{l}\text { [Kent ] [Mind]Sadness,mental } \\
\text { depression: (249) }\end{array}$ & 2 & 3 & 3 & 3 & 3 \\
\hline $\begin{array}{l}\text { [Kent ] [Sleep]Dreams:Falling :From high } \\
\text { places: (24) }\end{array}$ & 1 & 2 & & 3 & 1 \\
\hline [Kent ] [Stomach|Desires:Eggs: (4) & & & 2 & & \\
\hline $\begin{array}{l}\text { [Kent ] [Stomach]Desires:Cold :Food: } \\
\text { (14) }\end{array}$ & 3 & & & 2 & 1 \\
\hline \multicolumn{6}{|l|}{$\begin{array}{l}\text { [Kent ] [Stomach]Desires:Onions, raw: } \\
(2)\end{array}$} \\
\hline $\begin{array}{l}\text { [Kent] } \\
\text { [Stomach]Desires:Sour,acids,etc.: (77) }\end{array}$ & 2 & 2 & 2 & 1 & \\
\hline [Kent] ] [Stomach]Aversion:Sweets: (12) & 2 & 2 & & & 2 \\
\hline [Kent ] [Skin]Eruptions:Papular: (24) & 1 & 2 & 2 & & 1 \\
\hline
\end{tabular}

Fig 1: Symptoms, repertorisation was done by Hompath firefly repertory software with using kent's repertory

\section{Selection of remedy and follow ups}

After repertorising (Using hompath firefly software) the case and subsequently referring to Materia medica the final remedy selected was Thuja occidentalis. Accordingly, the patient was prescribed Thuja occidentalis 200C 1 dose O.D. for 1 day, followed by a placebo and the patient was asked to report after 1 month. Further follow-ups are summarized in table-1.

Table 1: Medicine prescribed and follow-up records.

\begin{tabular}{|c|c|c|}
\hline Date & Observation and result & Medicine and potency \\
\hline 16.01 .2019 & - & $\begin{array}{c}\text { 1. Thuja occidentalis 200C } 1 \text { dose. } \\
\text { Placebo for 30 days }\end{array}$ \\
\hline 13.02 .2019 & $\begin{array}{c}\text { General condition of the patient is better, eruption dried } \\
\text { up for 15 days then comes to stand still. }\end{array}$ & $\begin{array}{c}\text { 1. } \\
\text { Phuja occidentalis 1000C 1 dose for one day. } \\
\text { Placebo for 30 days }\end{array}$ \\
\hline 15.03 .2019 & Few more eruptions dried up & 1. PLACEBO \\
\hline 16.04 .2019 & Improvement continues & 1. PLACEBO \\
\hline
\end{tabular}

\section{Discussion}

The typical molluscum lesion is pink colored or skincolored, umbilicated papule containing a greyish central plug. There may be one or many lesions. The face and genital regions are commonly involved ${ }^{[8]}$. In the majority of patients, molluscum contagiosum resolves without any residual scars. The disorder is benign and spontaneous resolution is the usual outcome, but it may take 12-24 months. Molluscum contagiosum causes mainly cosmetic concerns. In some individuals, the lesions may persist for 35 years and maybe disfiguring ${ }^{[1]}$. But in this case of molluscum contagiosum, the complete recovery was noted in 4 months span (figure-2 to figure-5). Characteristic symptoms were noted after detail case taking as per Dr. Hahnemann's Organon of Medicine [13], followed by analysis and repertorisation of the case with the help of Kent's repertory (using hompath firefly software) ${ }^{[14]}$, which gives a list of nearly suggestive medicines but with characteristic features, totality and with history of the case, Thuja Occidentalis was selected and follow-ups were done according to Dr. Kent's advise on second prescription and follow-ups ${ }^{[15]}$. 


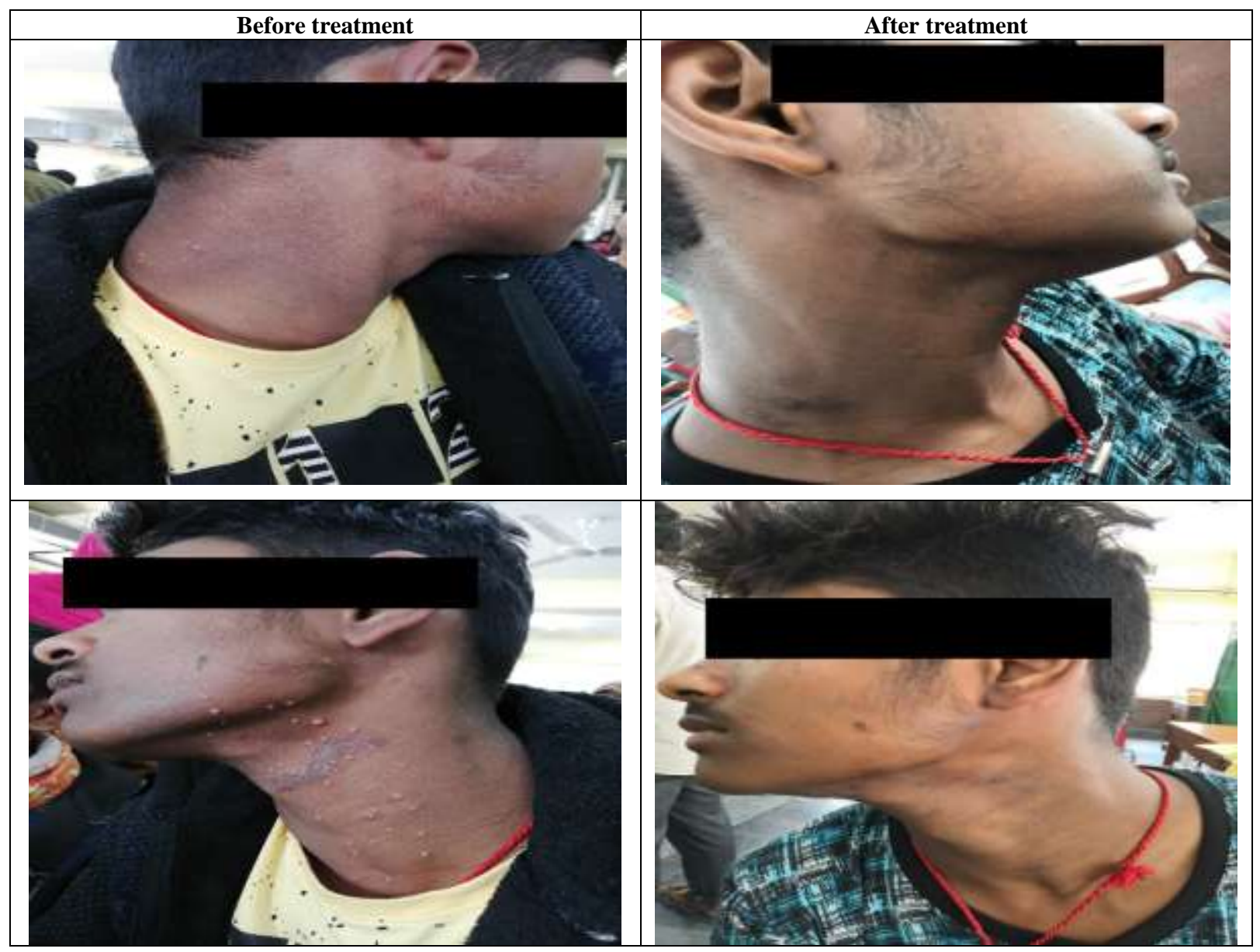

Conflict of interest: There is no conflict of interest.

\section{References}

1. Badri T, Gandhi GR. Molluscum Contagiosum. 2021 Mar 21. In: Stat Pearls [Internet]. Treasure Island (FL): Stat Pearls Publishing 2021.

2. Van der Wouden JC, van der Sande R, Kruithof EJ, Sollie A, van Suijlekom-Smit LW, Koning S. Interventions for cutaneous molluscum contagiosum. Cochrane Database Syst Rev 2017;5(5):CD004767. DOI: $10.1002 / 14651858 . C D 004767$.

3. Smith KJ, Skelton H. Molluscum contagiosum: Recent advances in pathogenic mechanisms, and new therapies. Am J Clin Dermatol 2002;3(8):535-45. DOI: $10.2165 / 00128071-200203080-00004$

4. Olsen JR, Gallacher J, Piguet V, Francis NA. Epidemiology of molluscum contagiosum in children: a systematic review. Fam Pract 2014;31(2):130-6. Doi: 10.1093/fampra/cmt075. Epub 2013 Dec 2. DOI: $10.1093 /$ fampra/cmt075

5. Forbat E, Al-Niaimi F, Ali FR. Molluscum Contagiosum: Review and Update on Management. Pediatr Dermatol 2017;34(5):504-15.

DOI: $10.1111 /$ pde. 13228

6. Meza-Romero R, Navarrete-Dechent C, Downey C. Molluscum contagiosum: An update and review of new perspectives in etiology, diagnosis, and treatment. Clin Cosmet Investig Dermatol 2019;12:373-81.

DOI: $10.2147 /$ CCID.S187224

7. Forbat E, Al-Niaimi F, Ali FR. Molluscum Contagiosum: Review and Update on Management. Pediatr Dermatol 2017;34(5):504-15.

DOI: $10.1111 /$ pde. 13228
8. Marks R. Roxburgh's common skin diseases. Ed. $7^{\text {th }}$. CRC Press 2019, P55-56.

9. Chen X, Anstey AV, Bugert JJ. Molluscum contagiosum virus infection. Lancet Infect Dis [Internet] 2013;13(10):877-88. Available from: http://dx.doi.org/10.1016/S1473-3099(13)70109-9. DOI: 10.1016/S1473-3099(13)70109-9

10. Edwards S, Boffa MJ, Janier M, Calzavara-Pinton P, Rovati C, Salavastru CM, et al. 2020 European guideline on the management of genital molluscum contagiosum. J Eur Acad Dermatology Venereol 2021;35(1):17-26. DOI: 10.1111/jdv.16856

11. Leung AKC, Barankin B, Hon KLE. Molluscum Contagiosum: An Update. Recent Pat Inflamm Allergy Drug Discov. [Internet] 2017;11(1):22-31. DOI: 10.2174/1872213X11666170518114456

12. Leung AKC. The natural history of molluscum contagiosum in children. Lancet Infect Dis [Internet]. 2015;15(2):136-7. Available from: http://dx.doi.org/10.1016/S1473-3099(14)71061-8. DOI: $10.1016 / \mathrm{S} 1473-3099(14) 71061-8$

13. Hahnemann S. Organon of medicine. B. Jain publishers (P) Ltd 2012.

14. Kent JT. Repertory of The homoeopathic materia medica. B. Jain publishers (P) Ltd 2012.

15. Kent JT. Lectures on homoeopathic philosophy. B. Jain publishers (P) Ltd 2012. 